\title{
Pierwsi po Bogu. Papieże w przekazie ikonograficznym obrazka religijnego
}

First after God: Popes in the Iconographic Transmission

\begin{abstract}
ABSTRAKT
Utrwalona w przekazie dogmatu o nieomylności papieża pozycja biskupa Rzymu w świecie chrześcijańskim możliwa jest do zobaczenia na obrazku religijnym. Jego ikonografia nie tylko informuje o atrybutach papiestwa, ale również symbolicznie pokazuje władzę i autorytet następcy św. Piotra. Jednak współcześnie w coraz większym stopniu postępuje profanizacja urzędu nauczycielskiego Kościoła, który przejmuje świeckie formy rytuału i odwołuje się w przekazie bardziej do aspektów emocjonalnych niż do dogmatyki wiary. Tym samym głowa Kościoła katolickiego w coraz większym stopniu staje się idolem, a nie przewodnikiem religijnym; celebrytq, a nie duchowym autorytetem. Postępuje kreacja nowego wzoru papiestwa: przywództwa jednego z nas, kierownictwa mianowanego, niewybieranego bezterminowo. Stawia to przyszłość obrazków religijnych z watykańskim imprimatur pod znakiem zapytania, gdy ich dewocyine przeznaczenie i sakralna wymowa ostatecznie zaniknq.
\end{abstract}

SLOWA KLUCZOWE obrazek religiiny, ikonografia chrześcijańska, dogmat o nieomylności papieża, autorytet religijny, praktyki dewocyine

\section{KEY WORDS}

the holy card,

the Christian iconography, the doctrine of infallibility of the pope,

the religious authority, devotional practices

SPI Vol. 20

2017/5/numer specjalny ISSN 2450-5358 e-ISSN 2450-5366 DOI: 10.12775/SPI.2017.5.003

I. Autorytet w Kościele 


\begin{abstract}
Assured by the transmission of the dogma of papal infallibility, the position of the Bishop of Rome in the Christian world is clear to see in religious images. Its iconography not only informs us about the attributes of the papacy, but also symbolically shows the authority of St. Paul and his successor Peter. However, the profaneization of the teaching office of the Church, which takes over the secular forms of ritual, is increasingly exacerbated, and refers more to the emotional aspects than the dogmas of the faith. Thus, increasingly the head of the Catholic Church has become an idol, not a religious leader, a celebrity, not a spiritual authority. The creation of a new papacy pattern follows: the leadership of one of us, appointed leadership, not elected without a deadline. This puts the future of religious imagery from the Vatican imprimatur under the question of when their devotional destiny and sacred word will eventually disappear.
\end{abstract}

Recepcja ustaleń soboru trydenckiego (1545-1563) oraz eksploracja rzymskich katakumb po 1578 roku stały za daleko idącą reformą ikonografii obrazka religijnego ${ }^{1}$. Dewocyjne artefakty utraciły rangę narzędzia wspierającego prywatny kult religijny, a stały się instrumentem odgórnego wpływania instytucji kościelnej na wiarę osób wierzących $^{2}$. W tym nurcie również tradycyjny przekaz czci oddawanej ziemskiemu następcy Chrystusa z racji jego apostolskiego autorytetu został wpisany w toczący się wówczas spór teologiczny i dogmatyczny wokół prymatu i nieomylności papieża3 ${ }^{3}$.

\title{
Formowanie się programu prezentacyinego
}

Aby przywrócić nadszarpniętą przez reformację jedność Kościoła, starano się narzucić biskupom obowiązek składania aktu posłuszeństwa biskupowi Rzymu, będącego mater et magistra w sprawach wiary i moralności. Rozbudowanemu obrzędowi homagium towarzyszyło

1 A. Przywara, Przedstawienia dewocyjne na obrazkach świętych jako przedmiot zainteresowań kolekcjonerskich, „Resovia Sacra” 2014, R. 21, s. 325.

2 A. Spamer, Das kleine Andachtsbild vom XIV. bis zum XX. Jahrbundert, München 1930, s. 61-62.

3 K. Schatz, Prymat papieski od początkórw do wspótczesności, przeł. E. Marszał, J. Zakrzewski, Kraków 2004, s. 191-197. 
wręczanie specjalnych drukowanych poświadczeń z podobizną kolejnego papieża ${ }^{4}$. W okresie wojen religijnych XVI-XVII wieku te miedziorytnicze błogosławieństwa docierały także do gromadzących się na okolicznościowych audiencjach świeckich dostojników, stając się dowodem ich przynależności do obozu katolickiego ${ }^{5}$. W misję budowania duchowej tożsamości wiernych wpisano kult męczenników, w których gronie znaleźli się również pierwsi następcy św. Piotra z okresu prześladowań ${ }^{6}$. Sugestywne modlitwy do starożytnych świętych, znajdujące się na drzeworytniczych odbitkach $z$ drukarni jezuickich Antwerpii i Wiednia, zawierały prośby o wsparcie głowy Kościoła w walce z jego nieprzyjaciółmi. Trafiały one do klasztorów i na parafie, gdzie rozprowadzano je w coroczny dzień uiszczania świętopietrza ${ }^{7}$.
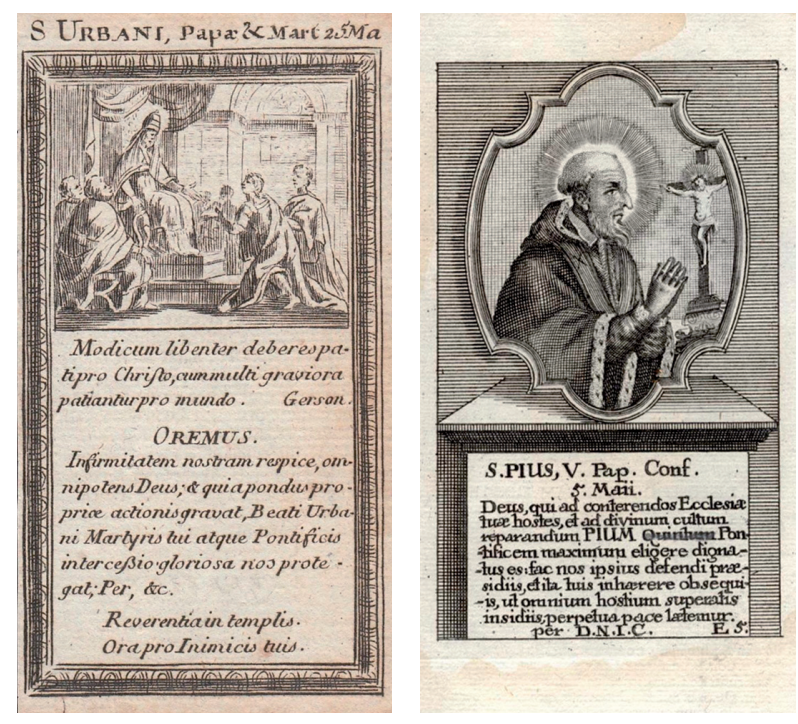

Fot. 1.

Kult świętych papieży w czasach nowożytnych (XVII-XVIII w.)

4 T. Fitych, Obraz biskupów polskich w oczach nuncjuszórw papieskich z potowy XVII wieku, w: Od Kijowa do Rzymu. Z dziejórw stosunków Rzeczpospolitej ze Stolica Apostolskq i Ukraina, red. M.R. Drozdowski, W. Walczak, K. Wiszowata-Walczak, Białystok 2012, s. 488. Por. H.D. Wojtyska, Papiestwo w XV-XVII w. w poszukiwaniu wtasnej tożsamości, „Kwartalnik Historyczny” 1985, nr 4, s. 913-916.

5 Por. M. Banaszak, Z dziejów dyplomacji watykańskiej. Poselstwa obediencyjne w latach 1534-1605, cz. 1., Warszawa 1975, s. 61-64.

6 Por. H. Misztal, Kult świętych, obrazó́w i relikwii w Kościele katolickim w aspekcie prawa kanonizacyjnego, „Roczniki Nauk Prawnych”1997, t. 7, s. 99.

7 R. Grześkowiak, J. Niedźwiedź, Nieznane polskie subskrypcje do emblematów Ottona van Veen i Hermana Hugona. Przyczynek do funkcjonowania zachodniej grafiki religijnej w kulturze staropolskiej, ,Terminus” 2012, z. 1, s. 54. 
Wzmocnieniu słabnącej w Europie pozycji politycznej Państwa Kościelnego służyło również organizowanie uroczystości beatyfikacyjnych i kanonizacyjnych poprzednich papieży, zwłaszcza tych, którzy zasłużyli się w dziele obrony Piotrowego prymatu (fot. 1). Przykładowo, w stulecie śmierci trydenckiego reformatora Kościoła Piusa V, w obliczu zagrożenia inwazją turecką, papież Klemens X w 1672 roku uczynił tego „szermierza kontrreformacj”” błogosławionym, a Klemens XI w 1712 roku podniósł go do rangi świętego, co samo w sobie stanowiło wyraz protestu wobec inwazji Habsburgów na Półwysep Apeniński ${ }^{8}$. W duchu oporu wobec ingerencji europejskich monarchów w wewnętrzne stosunki w Państwie Kościelnym wyniesiono na ołtarze średniowiecznych papieży, którzy szczególnie zabiegali o wysoką pozycję Kościoła: w 1713 roku beatyfikacji dostąpił Grzegorz X, a w 1736 roku Benedykt $\mathrm{XI}^{9}$. O politycznej i religijnej roli tych dostojników miały informować pojawiające się $\mathrm{w}$ trakcie ekspozycyjnych uroczystości wydrukowane inskrypcje, które przesyłano również do lokalnych Kościołów wraz z dołączonymi do obrazków fragmentami wydobytych z katakumb bądź nagrobków relikwii ${ }^{10}$. Tym samym dewocyjne kartki stawały się skutecznym narzędziem oddziaływania na wiernych w celu utrwalenia u nich postaw lojalności wobec Rzymu, co z oczywistych względów, zwłaszcza w epoce Oświecenia, nie było sprawą łatwą. Aby wzmacniać autorytet papieski, sięgano po środki nadzwyczajne: hojnie obsypywano drukarzy zezwoleniami na wyłączność do wytwarzania i dystrybuowania świętych obrazków w zamian za propagowanie na nich treści dostarczonych przez rzymską kurię. Pierwsze $\mathrm{z}$ nowego prawa skorzystały w 1738 roku wenecka rodzina Remondinich i zakład Solianich z Modeny, potem wydawca Martin Engelbrecht z Augsburga ${ }^{11}$. Kres wytwórczości okazjonalnej położyła rewolucja francuska. Wraz z zajęciem Rzymu przez wojska francuskie w 1798 roku papiestwo znalazło się w poważnym kryzysie: zarówno Pius VI, jak i Pius VII zostali uwięzieni i pozbawieni realnego

8 J.N.D. Kelly, Encyklopedia papieży, przeł. T. Szafrański, Warszawa 1997, s. 374-376.

9 R. Fischer-Wollpert, Leksykon papieży, przeł. B. Białecki, Kraków 1996, s. 107, 275-277.

10 Por. L. Borello, Arte e devozione nelle immaginette (sec. XVIII-XX), Torino 1991, s. 18-19.

11 Por. E.G. Grigioni, V. Pranzini, Santini. Piccole immagini devozionali a stampa e manufatte dal 17 al 20 secolo, Ravenna 1990, s. 11. 
wpływu na sprawy Kościoła ${ }^{12}$. Tymczasem dzięki wynalezionej w 1796 roku przez Aloisa Senefeldera litografii, na masową skalę zaczęto produkować artefakty o treści religijnej, pozbawione kościelnego imprimatur. Zyskały one renomę $z$ uwagi na poszerzanie się spectrum dewocyjnych praktyk, którym oddawali się wierni bez wsparcia i zaangażowania hierarchii ${ }^{13}$. Zwrot w stronę duchowości i spirytualizmu wzmacniał jednak te aspekty działań papiestwa, które szły w stronę odrodzenia życia religijnego. Głośnym echem w Europie odbiło się wydarzenie z 15 sierpnia 1811 roku, kiedy to Pius VII, odprawiający mszę św. w uroczystość Wniebowzięcia NMP, jak zaświadczali towarzyszący mu żołnierze francuscy, zaczął lewitować ${ }^{14}$. Z miejsca zaczęto rozprowadzać litograficzne odbitki tego zdarzenia z sugestywnymi napisami i modlitwami za papieża. W dzieło to zaangażowało się wielu nowych wydawców, m.in. Jean Charles Pellerin z powołanej do życia w 1796 roku obrazkarni w Épinal w Wogezach czy szwajcarski drukarz z Einsiedeln Joseph Charles Benziger ${ }^{15}$. Pius VII zasłynął również wsparciem, jakiego udzielił rodzącej się dopiero fotografii, zezwalając na wykonanie zdjęcia ze swoją podobizną w 1822 roku $^{16}$. Pozwoliło to na uruchomienie procesu budowy oficjalnego wizerunku papiestwa, odznaczającego się z jednej strony monarszym dostojeństwem, z drugiej usztywniającą zachowania pompatycznością (fot. 2). Od pontyfikatu Grzegorza XVI (1831-1846) w portrecie biskupa Rzymu dominuje ujęcie sylwetki z profilu, co bezpośrednio ma nawiązywać do okresu wczesnego cesarstwa, kiedy majestat władzy wyrażały odchylone do tyłu czoło, mocno osadzone w czaszce oczy, wydatny, lekko zakrzywiony nos, uchylone usta i odstający podbródek. Ubiór Ojca Świętego miała cechować oszczędność, dlatego obok białej sutanny eksponowana była jedynie piuska. Całość kompozycji zawierała się zwykle w medalionie ozdobionym dodatkowo herbem papieskim lub

12 R.P. McBrien, Leksykon papieży. Pontyfikaty od Piotra Apostota do Jana Pawta II, przeł. B. Mierzejewska, A. Miziołek, Warszawa 2003, s. 230.

13 M.T. Engels, Das kleine Andachtsbild. Prägedrucke und Stanzspitzenbilder des 19. Jahrbunderts, Recklinghausen 1983, s. 9-10.

14 Pius VII, w: Podręczna Encyklopedya Kościelna, opr. S. GALL, t. XXXI-XXXII, Warszawa 1913, s. 222-223.

15 A. Spamer, Das kleine Andachtsbild vom XIV. bis zum XX. Jahrhundert, dz. cyt., s. 266, 269.

16 S. Petersen, Joseph Nicéphore Niépce, w: Encyclopedia of nineteenth-century photography, red. J. Hannavy, New York 2008, s. 1004. 
innym symbolem kojarzącym się z władzą pontifexa, jak tiara czy mitra $^{17}$.

Fot. 2.

Formowanie programu prezentacyjnego za Piusa VII (1812)

i Grzegorza XVI (1831)
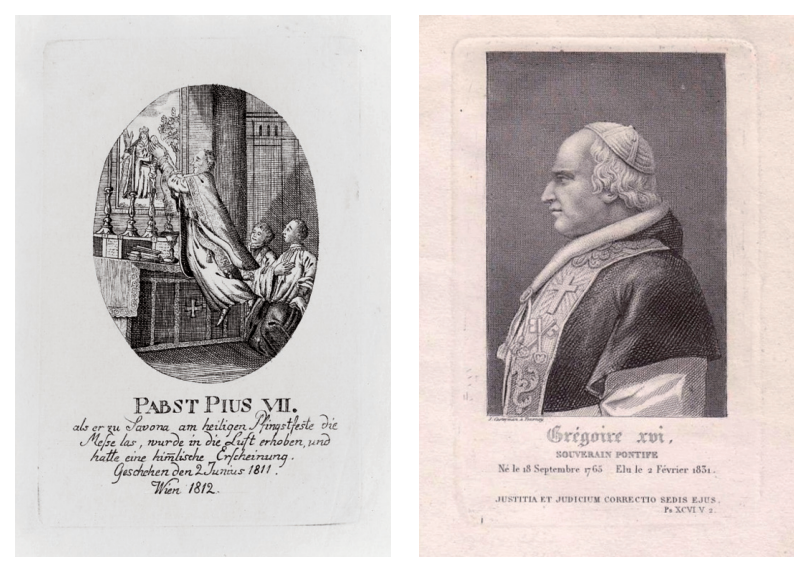

\section{Kreacja nurtu apologetycznego}

Przekaz ikonograficzny nabrał szczególnego znaczenia za Piusa IX, który najdłużej sprawował swój urząd: trzydzieści jeden lat, siedem miesięcy i dwadzieścia jeden dni, co z oczywistych względów umożliwiało opracowanie kompleksowej formy prezentacji papiestwa. Wbrew oczekiwaniom nie doszło do liberalizacji jego stylu, gdyż ten namiestnik Chrystusa prowadził ultrakonserwatywną politykę: w 1864 roku wydał słynny Syllabus z zestawem potępianych przez Kościół poglądów oraz zwołał Sobór Watykański I (1869-1870), który zdefiniował prymat i nieomylność papieża ${ }^{18}$. Wraz z nasileniem ruchów liberalnych i rewolucyjnych na terenie Włoch oraz w obliczu zagrożeń integralności terytorialnej Państwa Kościelnego najistotniejszą kwestią dla niego było utrzymać w Kościele przeświadczenie, że trwałość papiestwa jest sprawą kluczową i niepodważalną. Służyło temu wypuszczanie obrazków tzw. sukcesji apostolskiej, które na awersach zawierały wizerunek Chrystusa przekazującego św. Piotrowi władzę nad Kościołem w symbolicznym geście wręczenia kluczy, a na odwrotnej

17 M. Parzuchowska, Święte obrazki. Bóg i Ojczyzna, Warszawa 2016, s. 32.

18 R.P. McBrien, Leksykon papieży. Pontyfikaty od Piotra Apostota do Jana Pawta II, dz. cyt., s. 237. 
stronie modlitwę za „wiernego sługę pasącego owce"19. Mocno eksponowano treść ewangelicznego przekazu: „Ty jesteś Piotr-Skała, i na tej Skale zbuduję Kościół mój, a bramy piekielne go nie przemogą" (Mt 16,18), wprowadzając do ikonografii powiązany z nim motyw niwelowania przez Chrystusa własną osobą możliwego dla Kościoła zagrożenia. W nurcie tym ukazywano papieża i hierarchów w łodzi dryfującej na wzburzonych falach i pocieszanych m.in. obecnością gołębicy Ducha Świętego ${ }^{20}$. W odmianie wspomnianej konwencji to najwyższy pontifex umożliwiał spokojny sen Chrystusowi w duchowej łodzi miotanej przez symboliczne fale ateizmu, gdyż oświecony bożą mądrością rzymski patriarcha czuwał i nie pozwalał na obalenie jej napierającym zewsząd rewolucjonistom. W klimacie legitymizujących poszukiwań Pius IX wylansował obrazki tzw. „sekretnych modlitw” papieża, potwierdzające jego duchową więź z Bogiem i Maryją, którą ogłosił Niepokalanie Poczętą w 1854 roku. Na ozdobionych papierową koronką druczkach święte postacie przekazywały klęczącemu biskupowi Rzymu symboliczne przedmioty obrazujące jego cierpienia za Kościół i świat. Czasem udzielały błogosławieństwa jako umocnienia na drogach pełnionej posługi (fot. 3). W duchu solidaryzmu z sytuacją „więźnia Watykanu”, pozbawionego de facto ziemskiej władzy, rozprowadzano obrazki klęczącego za kratami papieża, stylizowanego
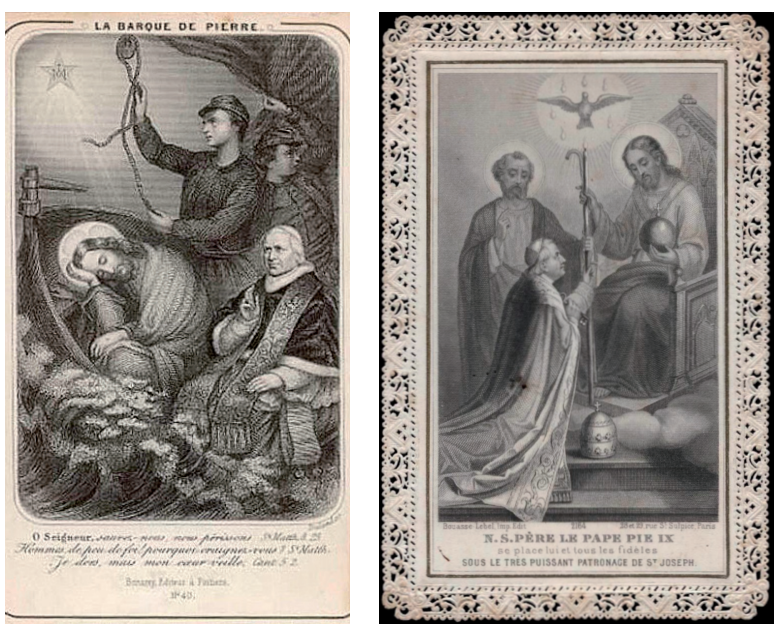

Fot. 3.

Legitymizacja władzy papieża za Piusa IX (1846-1878)

19 M. Parzuchowska, Święte obrazki. Bóg i Ojczyzna, dz. cyt., s. 31.

20 M. Parzuchowska, Święte obrazki. Częśś 3. Święci i btogostawieni, Warszawa 2015, s. 182. 
bądź na udręczonego biczowaniem Chrystusa w ciemnicy, bądź częściej na zakutego w kajdany św. Piotra. W takim wypadku sugestywne treści na rewersach druczków informowały, że z boską interwencją, podobnie jak to było w przypadku pierwszego biskupa Rzymu, możliwe jest uwolnienie papieża z politycznych opresji nawet po ludzku nierozwiązywalnych ${ }^{21}$. Apologetyczny wydźwięk uzyskały kartki wręczane wiernym na pamiątkę otrzymania absolucyjnego błogosławieństwa Urbi et Orbi ${ }^{22}$. Drastyczne ograniczenie możliwości jego udzielania po zajęciu Rzymu przez wojska włoskie w 1870 roku jeszcze wzmogło tę

Fot. 4.

Apologia władzy papieskiej za Piusa IX (1846-1878) i Piusa X (1903-1914)
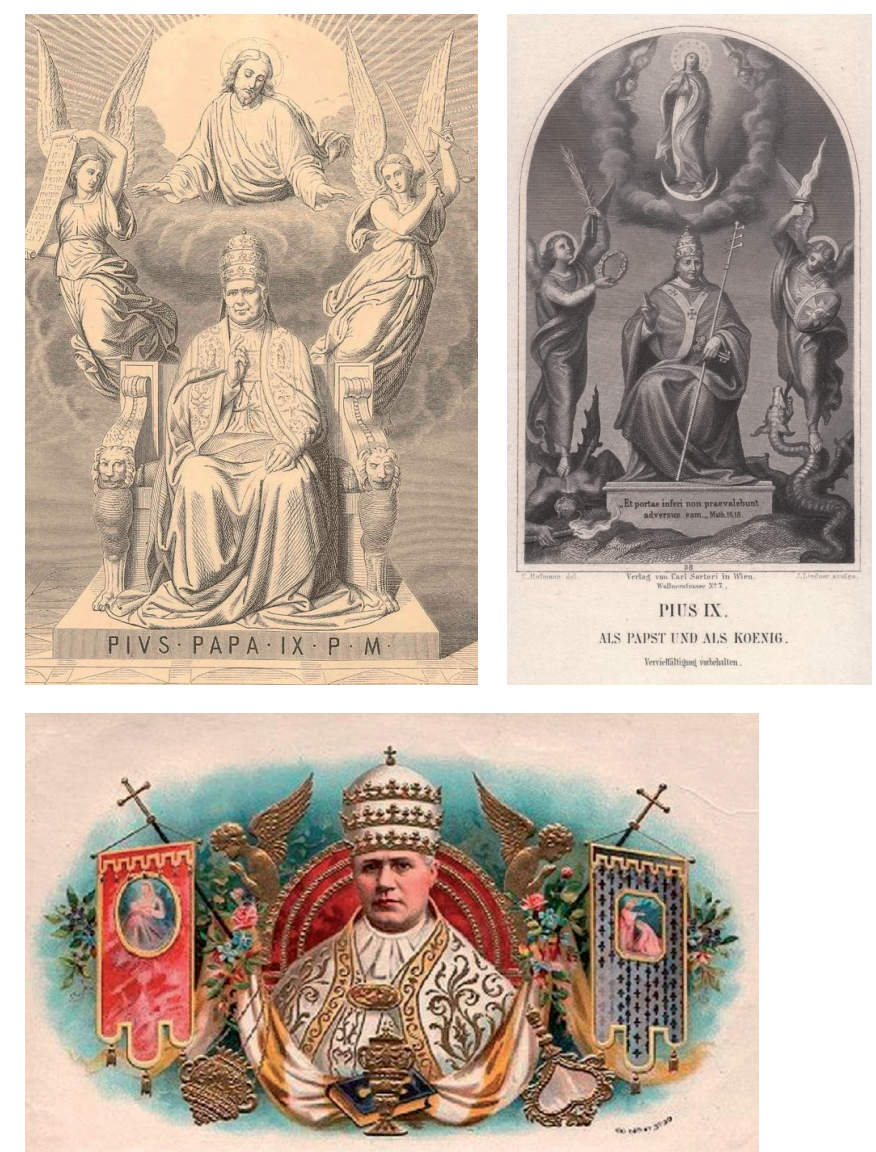

21 F. Cammarano, A. Florian, Santini e Storia di un Editore parigino. Maison Bouasse-Lebel, Marene 2009, s. 35.

22 A.B. Meehan, Urbi et Orbi, w: The Catholic Encyclopedia, vol. 15, red. Ch.G. Herbermann, E.A. Pace, C.B. Pallen, New York 1912, s. 221. 
praktykę, która zawęziła się do Bazyliki św. Piotra i wielkich świąt kościelnych. $Z$ tytułu wzrastających potrzeb wiernych oraz dla realizacji celów politycznych Pius IX nakazał koncesjonowanym litografom przygotować ryciny tronującego papieża w szatach pontyfikalnych z tiarą na głowie i pastorałem bądź kluczami św. Piotra w ręku (fot. 4). Biskupowi Rzymu w prezentowanym na druczkach obrzędzie błogosławieństwa asystują zwykle aniołowie ze swymi atrybutami: św. Michał z mieczem i wagą, często zabijający diabelskiego smoka, oraz św. Gabriel depczący Lucyfera z gałązką palmową w ręku lub księgą przeznaczenia, której zapis otwiera zbawionym drogę do raju. Całości prezentacji towarzyszy wizerunek Chrystusa, opiekuna Kościoła, bądź Maryi w pozie Wniebowzięcia. Istotnym dopełnieniem obrazu są umieszczane poniżej ryciny wersety z Pisma Świętego, przekonujące co do trwałości Kościoła i jego praworządności, oraz sugestywne napisy sławiące papieża. Rewers obrazków stanowi tekst błogosławieństwa Urbi et Orbi bądź inna okolicznościowa modlitwa. Za pontyfikatu Piusa X zredukowano na druczkach prymatu wiele ikonograficznych treści, wprowadzając m.in. zamiast świętych postaci symbolizujące je maryjne i chrystologiczne feretrony. Zniknął tron papieski, choć pozostał zarys jego oparcia, a archaniołów zastąpiły putta. Podpisaniu traktatów laterańskich w 1929 roku towarzyszyło wypuszczenie bardziej profanicznych artefaktów czci, oddających nowy charakter relacji między Watykanem a rządem włoskim. Na okolicznościowych druczkach centralnie osadzony medalion prezentował papieża Piusa XI udzielającego błogosławieństwa królowi Wiktorowi Emanuelowi III i premierowi Benito Mussoliniemu. Mocniej prymat papieski podkreślały obrazki ze mszy dziękczynnej za to wydarzenie, na których biskup Rzymu w stroju pontyfikalnym z tiarą na głowie, mając u boku sekretarza stanu kardynała Pietro Gasparriego, przyjmuje hołd od rządu włoskiego. Król wręcza papieżowi gałązkę oliwną na znak wiecznego przymierza, a świadkiem tak doniosłej dla Kościoła ceremonii jest Chrystus w otoczeniu aniołów ${ }^{23}$. Pogłębieniu symbolicznej wymowy ikonografii drukowanych sacromaterialności służyły obrazki jubileuszowe i okolicznościowe, wydawane $z$ racji rocznicowych uroczystości religijnych ${ }^{24}$. Ich charakter firmowały specjalne rzymskie

23 E.G. Grigioni, V. Pranzini, Santini. Piccole immagini derozionali a stampa e manufatte dal 17 al 20 secolo, dz. cyt., s. 76.

24 M. Parzuchowska, Święte obrazki. Częśs 1. Znak Krzyża Świętego, dz. cyt., s. 59. 
dykasterie, które realizowały wytyczne dekretu Leona XIII „Officiorum ac munerum" z 1897 roku $^{25}$. Dokument narzucał koncesjonowanym wydawcom obowiązek uzyskania imprimatur poświadczającego zgodność treści i formy z przyjętym w papieskiej kurii programem prezentacyjnym. Odpowiadał on zarówno lokalnej tradycji kościelnej, jak i wymogom misji na obszarach pozaeuropejskich, gdzie był szczególnie istotny z racji konieczności utrzymania religijnej łączności z Rzymem ${ }^{26}$. W tym aspekcie interesującym przykładem obrazka jubileuszowego jest artefakt z 1903 roku, ukazujący Leona XIII na tle watykańskich ogrodów, które zawierały egzotyczne rośliny z całego świata, w tym eksponaty pochodzące z Ziemi Świętej (fot. 5). Słabnący na siłach papież podpiera się na lasce, ale wciąż jest zdolny do

Fot. 5.

Artefakty jubileuszowe Leona XIII (1878-1903) i Piusa X (1903-1914)
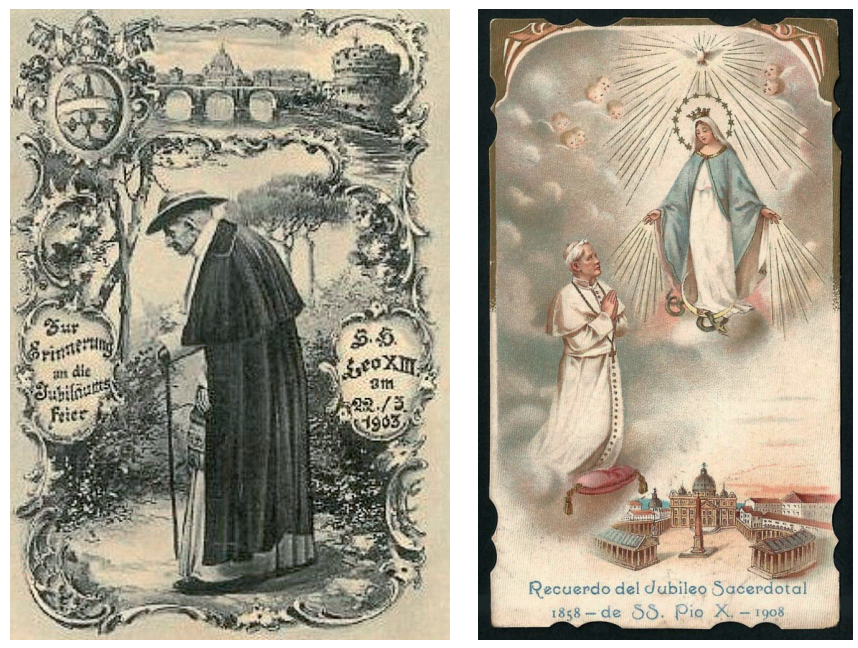

kontrolowania i kierowania Kościołem tak różnorodnym w swej istocie, jak wspomniany ogród. Oczywiście przesłanie jest bardziej wymowne w okolicznościach niesprzyjających, gdy słabnie prestiż papieża w związku z prezentowanym przez niego stanowiskiem wobec świata.

25 A. Spamer, Das kleine Andachtsbild vom XIV. bis zum XX. Jabrbundert, dz. cyt., s. $268-269$.

26 Na przełomie stuleci było ponad 120 drukarń papieskich w świecie, które produkowały pół biliona obrazków rocznie. Niemniej wzorników apologetycznych było niewiele. $\mathrm{W}$ ikonografii dominowały symbole chrysto- i mariologiczne oraz sceny biblijne. Por. C. McDannell, Material Christianity: Religion and Popular Culture in America, New Haven 1995, s. 167-174. 

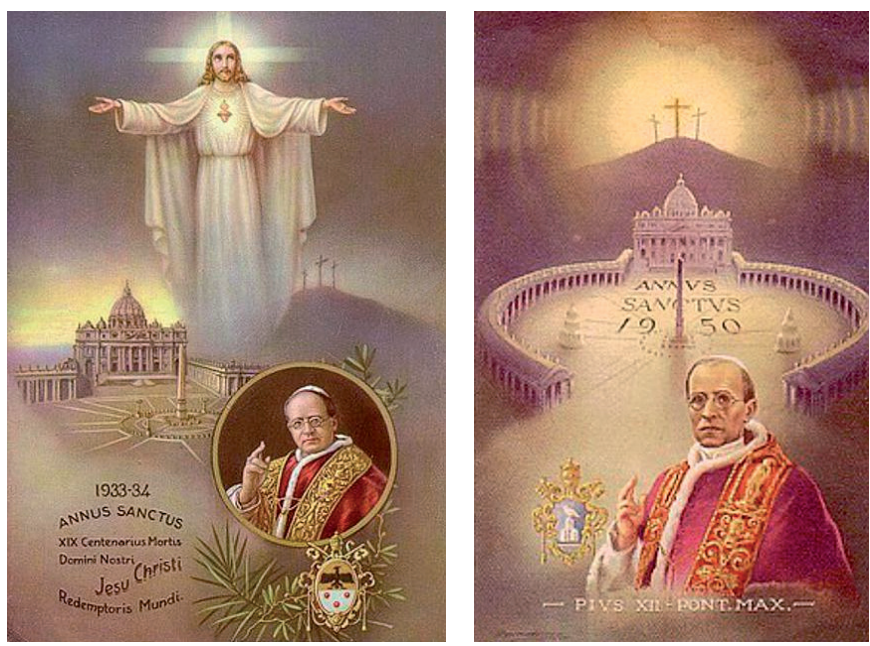

Fot. 6.

Okolicznościowe sakramentalia z czasów Piusa XI (1922-1939) i Piusa XII (1939-1958)

Wydany z racji sekundycji (pięćdziesiątej rocznicy święceń) w 1908 roku obrazek jubileuszowy Piusa X zwraca uwagę na toczący się ówcześnie w Kościele spór z modernizmem. Jego skutkiem było nałożenie na duchownych obowiązku przysięgi wierności katolickim dogmatom ${ }^{27}$. Dla potwierdzenia obecnej w Kościele wiary w cuda i objawienia papież zostaje na obrazku zaprezentowany, gdy doznaje podczas modlitwy wizji Niepokalanej Dziewicy. Jej zostaje powierzony Kościół, symbolicznie ukazany w postaci bazyliki św. Piotra i placu watykańskiego. Podobny motyw towarzyszy artefaktom okolicznościowym, głównie związanym z obchodami rocznicowymi narodzin Chrystusa i pamiątki jego śmierci. Dla uczczenia dziewiętnastego stulecia od zmartwychwstania Jezusa, w 1933 roku wypuszczono obrazki z podobizną Piusa XI, który błogosławi wiernym ze wzgórza watykańskiego (fot. 6). Sylwetce pontifexa towarzyszy postać Chrystusa, który rozpościera szeroko ramiona i pokazuje gorejące serce. W tle majaczy Golgota z trzema krzyżami jako symbolami tajemnicy odkupienia. Rewers jest opisem rzymskich uroczystości oraz możliwości uzyskania absolucji z racji obchodzonego święta. Podobną wymowę posiada artefakt z 1950 roku, kiedy Pius XII ogłosił rok święty dla zamknięcia wojennych rozliczeń ${ }^{28}$. Przybywający na uroczystości wierni

27 R.P. McBrien, Leksykon papieży. Pontyfikaty od Piotra Apostoła do Jana Pawta II, dz. cyt., s. 245.

${ }^{28}$ J.N.D. Kelly, Encyklopedia papieży, dz. cyt., s. 448. 
otrzymywali pamiątkowe obrazki ukazujące nie tylko błogosławiącego ich papieża, Rzym i Golgotę, ale również zdążające ku Chrystusowi niezliczone tłumy cierpiących i zmęczonych ludzi. Pociechę niosła im znajdująca się na odwrocie kartek modlitwa błagalna, która nakierowywała ich uwagę na rolę papieża jako tego pasterza, któremu Bóg dał prawo odpuszczania win praktycznie nieodpuszczalnych, jak zbrodnie ludobójstwa. Tym samym zmieniało się dotychczasowe przesłanie ikonograficzne: surowość ustępowała oznakom ludzkiej wrażliwości i empatii. Zwrot w stronę humanizmu zapoczątkowały obrazki kanonizacyjne Piusa X z 1954 roku, które ukazywały tego „eucharystycznego papieża”, jak o nim mówiono, w pozie dobrotliwego starca, zdolnego do pochylenia się nad potrzebami małych dzieci pragnących wcześnie otrzymać Komunię świętą ${ }^{29}$. Mocny asumpt dały również kommemoratywne pamiątki z pogrzebu Jana XXIII w 1963 roku, ukazujące jego nagrobek w bazylice św. Piotra. Grób „papieża dobroci” zdobiły światła ze wszystkich kontynentów i ukochane kwiaty. Sylwetka zmarłego biskupa Rzymu była wyeksponowana w medalionie na kształt kanonizowanych świętych, co tym bardziej podkreślało powszechne przekonanie wiernych, iż Jan XXIII winien być szybko wyniesiony na ołtarze ${ }^{30}$. Emocjonalna ekspresyjność stała się wyrazem

Fot. 7.

Humanizacja przekazu ikonograficznego u Jana XXIII (1958-1963) i Pawła VI (1963-1978)
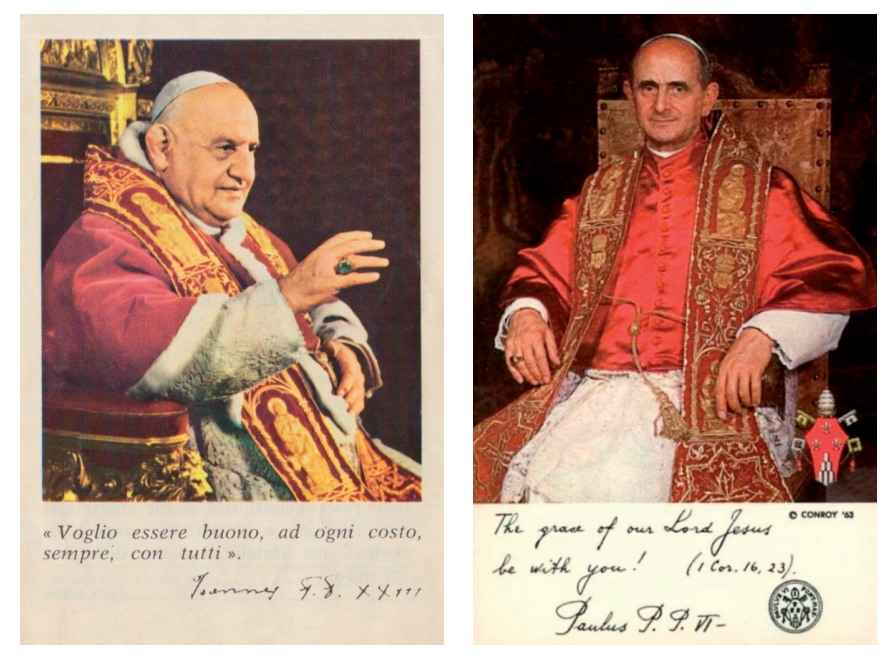

29 Z. Zieliński, Pius X, w: Encyklopedia katolicka, t. 15, red. E. Gigilewicz, Lublin 2011, s. 756-757.

30 M. Parzuchowska, Święte obrazki. Częśś 3. Święci i btogostawieni, dz. cyt., s. 183. 
nowego trendu w ikonografii za pontyfikatu tzw. papieży soborowych. Zarówno Jan XXIII, jak i Paweł VI otwarli możliwość bardziej swobodnej prezentacji ich osoby na oficjalnych wzornikach (fot. 7). Wypuszczane przez rzymskie i mediolańskie drukarnie artefakty zaczęły zdobić fragmenty wypowiedzi papieskich i ich osobiste podpisy. Dzięki praktyce powielania druczków $z$ tymi napisami upowszechniają się charakterystyczne dla papieży zwroty, obrazujące ich osobę oraz pontyfikat. Z tego tytułu Jan XXIII będzie znany jako autor sentencji "Chcę być dobrym dla wszystkich”, a Paweł VI błogosławieństwa „Niech łaska i pokój będą z Wami”. Przeobrażeniom w stronę form mniej patetycznych ulegał również utrwalony tradycją ceremoniał czci i towarzyszące mu redyspozycje. Praktycznie pod koniec pontyfikatu Piusa XII zaniechano w trakcie prywatnych audiencji zwyczaju całowania papieża w pierścień, kolano i stopę, a właściwie w wyszyty na czerwonych pantoflach krzyż. Dokonującym obrzędu wręczano potwierdzające akt druczki z papieskim błogosławieństwem. Zawierały one oficjalny portret biskupa Rzymu oraz watykańskie emblematy i okolicznościowe inskrypcje. Podobną wymowę miały obrazki sedia gestatoria (fot. 8). Pojawiły się wraz z pontyfikatem Piusa VIII (1829-1830), będąc wyrazem sprzeciwu wobec mnożących się wśród katolików postaw sekularyzmu. Towarzyszyły obrzędom koronacyjnym, kiedy wnoszono lektykę papieską i ceremonialnie palono przed nią dokumenty poprzednika, śpiewając sugestywny hymn „Tak oto przemija chwała tego świata”. Dworzanie podnosili tron, aby
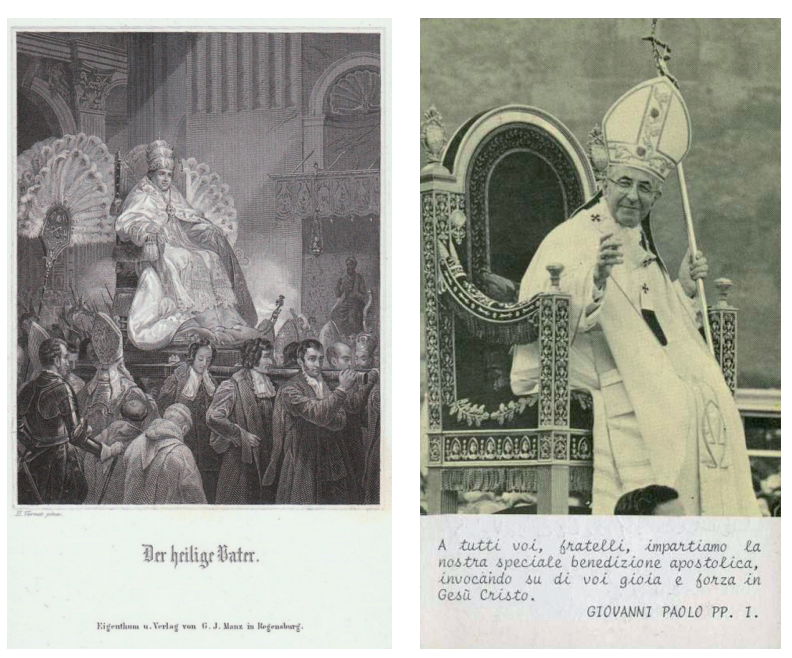

Fot. 8.

Wygląd sedia gestatoria Piusa VIII (1829-1830)

i Jana Pawła I (1978) 
zebrani łatwiej mogli dostrzec odznaki władzy pontifexa, zwłaszcza pierścień Rybaka. Powoli przemieszczającą się w bazylice św. Piotra procesję poprzedzali gwardziści szwajcarscy oraz szlacheccy pretorianie niosący berła biskupa Rzymu, zaś zamykało ją dwóch szambelanów dworu dźwigających wachlarze z piór strusich. Ostatni taki pochód odbył się w 1978 roku z okazji wyboru Jana Pawła I i stanowił zwieńczenie długiej tradycji podnoszenia pontifexa dla aplauzu rzymskiego ludu i czci monarszej ${ }^{31}$. Obrzędowi zawsze towarzyszyło rozdawanie okolicznościowych druczków z modlitwą za papieża i wersetami z Pisma Świętego. Niektóre obrazki zawierały też tekst błogosławieństwa i dołączone relikwie z rzymskich katakumb. Charakterystyczne dla współczesnych papieskich artefaktów jest zlaicyzowanie ich ikonograficznego przekazu. Istotne dla wiernych pontyfikalne sakramentalia stają się coraz częściej jedynie pamiątkowymi obrazkami, które można traktować jak karty pocztowe lub fotograficzne odbitki (fot. 9). Dużą rolę w tym procesie odegrało urzędowe zatwierdzenie wizerunku papieża, jakie nastąpiło za pontyfikatu Piusa XII po nieudolnych próbach mistyfikacji podejmowanych przez włoskich faszystów w czasie wojny $^{32}$. Oskarżenie o ,apartamentowe rządy” zaowocowało większą otwartością Stolicy Apostolskiej na przekaz medialny. Na fotografików watykańskiej gazety „L’Osservatore Romano” spadł obowiązek towarzyszenia głowie Kościoła w codziennych czynnościach oficjalnych i prywatnych, aby jak najobszerniej udokumentować papieski pontyfikat i uczynić go bardziej przejrzystym dla wiernych. Istotnym przełomem był czas Soboru Watykańskiego II, kiedy akredytowano w rzymskiej kurii blisko 70 fotografów. Wielu z nich, jak Lothar Wolleh, wpłynęło na obraz papiestwa, ukazując jego „nowoczesną twarz ubraną w archaiczny kostium" ${ }^{33}$. Niemniej ton artystycznej wypowiedzi przez 53 lata kształtował Arturo Mari, który wykonał ponad milion zdjęć sześciu ostatnich papieży ${ }^{34}$. Pontyfikalny obrazek Benedykta XVI z 2005 roku jest ostatnim jego dziełem wskazującym

31 P. Dudziński, Sedia gestatoria, w: Encyklopedia katolicka, t. 17, red. E. Gigilewicz, Lublin 2012, s. 1335.

32 M. Riebling, Church of Spies: The Pope's Secret War Against Hitler, New York 2015, s. 59-61.

33 L. Wolleh, Das Konzil, II Vatikanisches Konzil (The Council, Vatican II Ecumenical Council), Stuttgart 1965, s. 5-6.

34 Arturo Mari-cztowiek, którego zdjęcia opowiadają historię, „Niedziela” 2007, nr 41, s. 11. 


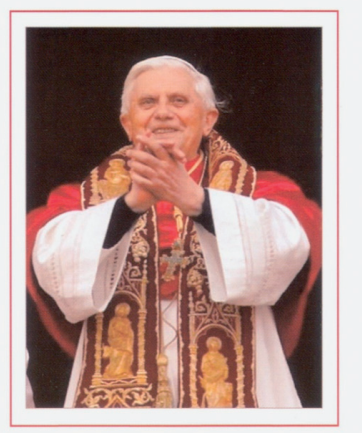

POPE BENEDICT XVI

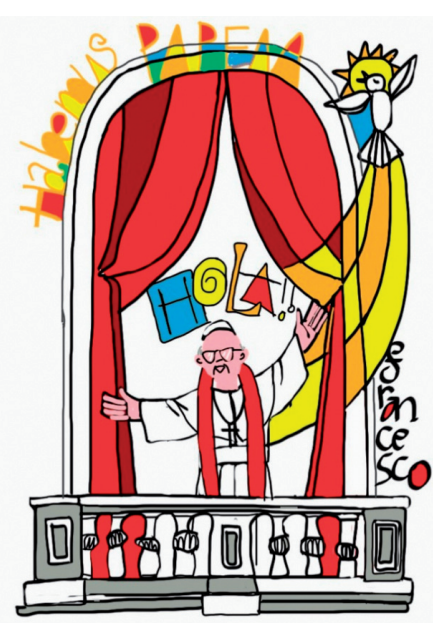

Fot. 9.

Obrazki pontyfikalne nurtu profanicznego Benedykta XVI (2005) i Franciszka (2013)

na tendencję do ekspresyjnego ujmowania nadzwyczajnych zdarzeń dziejących się w Watykanie. Na artefakcie nowo obrany papież cieszy się jak dziecko z nominacji i jest pełen życzliwej otwartości dla wiwatujących na jego cześć tłumów ${ }^{35}$. Trend w stronę pozytywnego marketingu kontynuowany jest również za pontyfikatu papieża Franciszka m.in. przez ilustratora Mickeya McGratha, który dla potrzeb amerykańskiego ruchu pielgrzymkowego wykonywał inauguracyjne zdjęcia. Jemu zawdzięczamy kolorowy obrazek z 2013 roku, ukazujący głowę Kościoła katolickiego na balkonie bazyliki św. Piotra w Rzymie w momencie ogłoszenia wiernym wyboru. Papież został zaprezentowany w konwencji zabawy jak celebryta, który beztrosko wita tłumy okrzykiem „Hola”. Rozrywkowy charakter uroczystości ma podkreślać Duch Święty przybierający postać prezenterki-gołębicy, zastępującej w obowiązkach kardynała protodiakona.

\section{Charakter polskiej wytwórczości dewocyinej}

Należy pamiętać, że wagę przekazu oficjalnego w szerszej perspektywie formowały Kościoły lokalne. Również dla ziem polskich, zwłaszcza doby zaborów, istotne było pytanie, na ile treść płynąca z Rzymu jest atrakcyjna dla Polaków i może stać się elementem ich religijnej tożsamości. Początkowo druczki trafiające nad Wisłę, głównie za

35 M. Parzuchowska, Święte obrazki. Bóg i Ojczyzna, dz. cyt., s. 33. 
pośrednictwem morawskich litografów, nie wzbudzały zainteresowania $^{36}$. Odstraszał brak przychylności dla sprawy polskiej ze strony Rzymu oraz nikły związek z maryjnością jako nurtem dominującej religijności. Dopiero pontyfikat Piusa IX okazał się przełomem, gdyż otwierał możliwości nowego spojrzenia na polską duchowość. Nie bez znaczenia było też przekonanie, że zamknięty w obrębie wzgórza watykańskiego ziemski namiestnik Chrystusa przechodzi równie ciężkie udręki, jak naród pozbawiony swej wolności. Nad Wisłą odczytywano to jako znak kary boskiej na papiestwo, które tak oddanych sprawie Kościoła Polaków obdarzało tak nikłym poparciem. Ponadto siłę integrującą naród wokół Rzymu wyrażały objawienia gietrzwałdzkie z 1877 roku, gdyż potwierdzały lansowany przez najwyższego pontifexa dogmat o Niepokalanym Poczęciu i wskazywały na duchową opiekę Maryi nad naszymi ziemiami ${ }^{37}$. Wysyp obrazków pochodzących z drukarń krakowskich i częstochowskich z watykańskimi emblematami nastąpił jednak dopiero za pontyfikatu Leona XIII (1878-1903). Momentem przełomowym było wydanie $z$ jednej strony encykliki społecznej „Rerum novarum” w 1891 roku, jak i bezpośrednio skierowanej do polskiego Kościoła encykliki „Charitatis providentiaeque"38. Papież stawał się rzecznikiem uciśnionych, co natychmiast przekładało się w ikonografii na rozbudowaną symbolikę kapłana-trybuna otrzymującego nominację wprost od Chrystusa. W serii obrazków z drukarni Józefa Angrabajtisa z lat 1898-1899 widzimy motyw dryfującego ku Polsce na falach wiślanych papieża, który z woli ukrzyżowanego Jezusa, życzliwie spoglądającego ku wzgórzu wawelskiemu, błogosławi narodowi rozerwanemu na trzy części i symbolicznie zszywanemu przez Maryję ${ }^{39}$. Całość prezentacji dopełnia na niektórych artefaktach napis „Jezus i Marya, ucieczko nasza” oraz znajdująca się na rewersie modlitwa o spełnienie „proroctw narodowych” ${ }^{40}$. Integracyjny

36 Por. A. Spamer, Das kleine Andachtsbild vom XIV. bis zum XX. Jahrhundert, dz. cyt., s. 273-274; T.M. Engels, Das kleine Andachtsbild. Prägedrucke und Stanzspitzenbilder des. 19. Jabrbunderts, dz. cyt., s. 21-22.

37 J. Żurek, „Da un paese lontano... Polscy biskupi i kaptani u śrw. Piotra (999-1978), „Biuletyn IPN” 2005, nr 4, s. 68

38 Ch. Cook, J. Stevenson, Leksykon nowożytnej historii Europy, przet. W. Gałąska, Warszawa 2000, s. 348; R. Fischer-Wollpert, Leksykon papieży, dz. cyt., s. 165.

39 M. Parzuchowska, Święte obrazki. Częśś 1. Znak Krzyża Świętego, Warszawa 2012, s. 57.

40 M. Parzuchowska, Święte obrazki. Częśí 2. Życie Śrwiętej Rodziny, Warszawa 2013, s. 48. 
charakter prezentują koronatki z 1910 roku, ukazujące klęczącego Piusa X, fundatora nowych koron do obrazu Matki Bożej Częstochowskiej, który na brzegu wiślanym modli się za Polskę ${ }^{41}$. Jest on obecny również na innych pamiątkach z wspomnianej uroczystości, co niewątpliwie podkreśla ścisły związek papiestwa z polskim Kościołem (fot. 10) ${ }^{42}$. Nie bez znaczenia dla popularności tego typu artefaktów był fakt powielania na ulotnych drukach plotki o śląskim pochodzeniu rodziny Piusa X i proroctw, jakoby przekazanych mu we śnie, o wyniesieniu Polski na końcu czasów ${ }^{43}$. Świadectwem znaczenia nad Wisłą

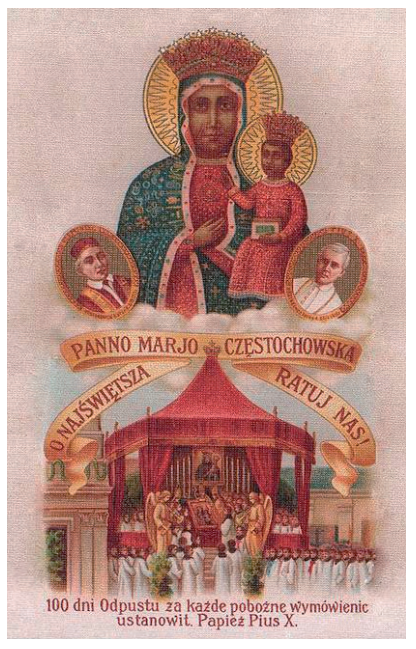

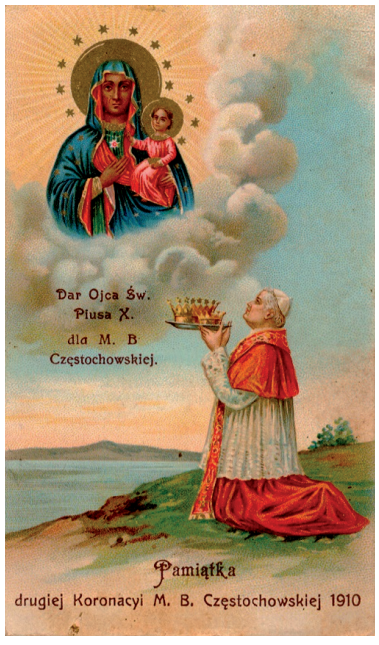

Fot. 10.

Pamiq̨tki koronacyine

z wizerunkiem Piusa X (1910)

osoby ziemskiego namiestnika Chrystusa były także kolejne obrazki z wizerunkami papieży: Piusa XI z kanonizacyjnych druczków Andrzeja Boboli z 1938 roku oraz Piusa XII modlącego się za udręczoną wojną Polskę z 1944 roku. Kiedy w 1958 roku została otwarta kaplica Matki Bożej Częstochowskiej w grotach watykańskich, fakt odprawienia przed obrazem jasnogórskim mszy św. przez Piusa XII stał się

41 M. Parzuchowska, Święte obrazki. Częśs 1. Znak Krzyża Świętego, dz. cyt., s. 49.

42 Potwierdzeniem tego faktu było również uznanie pieśni „Z dawna Polski Tyś Królową, Maryjo” za hymn kościelny i zezwolenie na powielanie jej treści na posiadających papieskie imprimatur druczkach. W związku z tym na rewersach koronatek z 1910 roku znalazły się słowa: „Miej w opiece naród cały, który żyje dla Twej chwały. Niech powstanie znów wspaniały, Maryjo!”.

43 Por. R.P. McBrien, Leksykon papieży. Pontyfikaty od Piotra Apostota do Jana Pawta II, dz. cyt., s. 245; Zdementowano polskie pochodzenie Piusa X. Na historycznym kongresie w Opolu na Ślasku, „L'Osservatore Romano” 2013, nr 7, s. 62. 
elementem powielanych przez drukarnię mediolańską fotografii, które zaczęły docierać do Polski w postaci niewielkich kartek z modlitwą za papieża $^{44}$. W kraju masowo konfiskowano je, podobnie jak obrazki z Pawłem VI, który nie mogąc przybyć na uroczystości milenijne modlił się w Rzymie przed wizerunkiem Czarnej Madonny ${ }^{45}$. Kardynał Stefan Wyszyński umiejętnie wykorzystywał fakt ignorancji przez władze komunistyczne Stolicy Apostolskiej, powielając tzw. obrazki nawiedzenia i okolicznościowe pocztówki 1000-lecia Chrztu Polski z wizerunkami papieży Jana XXIII i Pawła VI ${ }^{46}$. Te powstałe $z$ inspiracji Instytutu Prymasowskiego w Częstochowie zawierały sugestywne napisy, np. inskrypcję „Pokój ludziom dobrej woli” z okazji świąt Bożego Narodzenia czy „Chrystus zmartwychwstał i my zmartwychwstaniemy" na Wielkanoc ${ }^{47}$. Artefakty te nie były jednak liczne i nie oddziaływały tak masowo, jak obrazki z Janem Pawłem II, które pojawiły się w Polsce niedługo po inauguracji pontyfikatu. Pierwsze wydała w listopadzie 1978 roku Księgarnia św. Wojciecha w Poznaniu w liczbie ponad 100 tys. egzemplarzy, opierając się na reprincie oficjalnej fotografii Karola Wojtyły zaraz po nałożeniu białej sutanny i piuski. Papież ma widocznie zmęczoną twarz, a łamiące się palce u rąk zdradzają odznaki niepokoju ${ }^{48}$. Dopiero w pełni profesjonalne zdjęcia zgodne z przyjętą w XIX wieku konwencją wizerunkową pojawiły się w związku z pierwszą pielgrzymką do Ojczyzny w czerwcu 1979 roku. Wykonane w Mediolanie pamiątkowe obrazki ukazywały pontifexa $\mathrm{w}$ pozie $\mathrm{z}$ ingresu oraz zawierały na rewersie odręczny tekst błogosławieństwa i podpis Jana Pawła $\mathrm{II}^{49}$. Pomimo podjętych przez Służbę Bezpieczeństwa działań polegających na przechwytywaniu i niszczeniu druków kościelnych, udało się rozprowadzić w trakcie uroczystości, głównie w Krakowie, blisko 30 tys. tych artefaktów ${ }^{50}$. Posłużyły

${ }_{44}$ K. Jarkiewicz, Ikona polskiej pamięci. Kult Matki Boskiej Częstochowskiej w świecie, w: Pamięć, kultura, edukacja, red. A.P. Bieś, M. Chrost, B. Topij-Stempińska, Kraków 2011, s. 83.

45 Por. Archiwum Akt Nowych, Główny Urząd Kontroli Prasy, Publikacji i Widowisk, Dziatalność Kościota rzymsko-katolickiego 1958-1963, sygn. 125/303, Notatka informacyjna w sprawie nadsytanych do kraju obrazków religijnych, k. 18.

46 M. Parzuchowska, Święte obrazki. Bóg i Ojczyzna, dz. cyt., s. 11.

47 M. Parzuchowska, Śrwięte obrazki. Częśś 2. Życie Śrwiętej Rodziny, dz. cyt., s. 44.

${ }_{48}$ M. Parzuchowska, Święte obrazki. Częś 3. Święci i btogostawieni, dz. cyt., s. 183.

49 M. Parzuchowska, Święte obrazki. Częś́ 1. Znak Krzyża Świętego, dz. cyt., s. 58.

50 R. Terlecki, Miecz i tarcza komunizmu. Historia aparatu bezpieczeñstwa w Polsce 1944-1990, Kraków 2007, s. 246; R. Łatka, Polityka wtadz PRL wobec 
one również do wykonania powiększeń zdobiących m.in. bramę Stoczni im. Lenina w Gdańsku w trakcie sierpniowych strajków 1980 roku. W zakładach pracy masowo rozprowadzano obrazki z tekstem przemówienia z Placu Zwycięstwa w Warszawie. Na tle watykańskiego godła i Białego Orła ukazywano sylwetkę zatroskanego losem Ojczyzny papieża, który dobitnie mówi: „Niech zstąpi Duch Twój i odnowi oblicze ziemi, tej ziemi" ${ }^{11}$. O związku Kościoła w Polsce z papiestwem miały też świadczyć druczki ukazujące Jana Pawła II z Prymasem w geście błogosławieństwa ${ }^{52}$. Zastąpiły one po 1981 roku te artefakty, które oddawały scenę homagium z nietypowym zakończeniem, czyli uściskiem i pocałunkiem kardynała Wyszyńskiego. Zmarły Prymas wyrastał bowiem na męża opatrznościowego, który doprowadził swoim działaniem do wyniesienia Polaka na stolicę Piotrową i z tego tytułu mógł być równy papieżowi. Silnie integrującą rolę odegrały papieskie artefakty jednak dopiero w okresie stanu wojennego (fot. 11). Druczki powielane przez podziemną „Solidarność” zawierały motyw udręczonego w oporze wobec komunizmu narodu i Jana Pawła II, który mówi „za nas i do nas”. Częstym symbolem były kraty nawiązujące do znanej ikonograficznej koncepcji więzienia św. Piotra, które w tym ujęciu

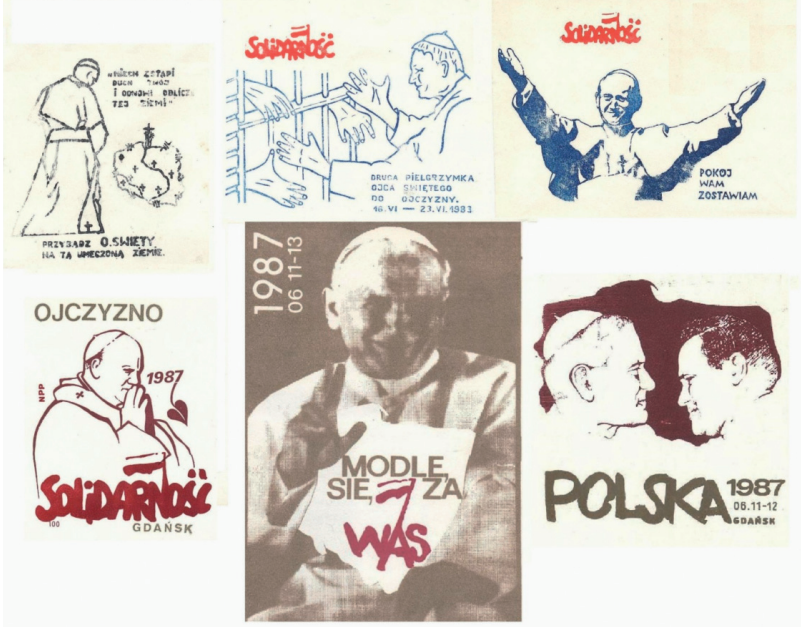

Fot. 11.

Obrazki pielgrzymkowe Jana Pawła II z drukarń podziemnej „Solidarności”

Kościoła katolickiego w województwie krakowskim w latach 1975-1980, w: PRL na pochylni (1975-1980), red. M. Bukała, D. Iwaneczko, Rzeszów 2017, s. 719;

G. Majchrzak, (Nie)chciany pielgrzym, „Biuletyn IPN” 2005, nr 4, s. 35.

51 M. Parzuchowska, Święte obrazki. Bóg i Ojczyzna, dz. cyt., s. 150.

52 M. Parzuchowska, Święte obrazki. Częśs 3. Święci i błogostawieni, dz. cyt., s. 56. 
nie jest otwierane mocą bożą, a wysiłkami papieża. Dzięki duchowemu wsparciu Chrystusowego namiestnika na ziemi, wyrażonemu również w słowach „Pokój zostawiam wam”, cierpienia przeżywane przez internowanych nie odbierały im nadziei, a wręcz przeciwnie, wzmagały wolę walki ze znienawidzonym systemem. W tym aspekcie oczywistym faktem wydawał się wysyp artefaktów intencjonalnych przed drugą i trzecią pielgrzymką do Ojczyzny, której program koncentrował się wokół spraw robotniczych i idei pracy ${ }^{53}$. Z tego tytułu też w 1983 roku władze w obawie rozruchów mocno kontrolowały zachowania społeczne, m.in. nie dopuszczając do powielania i dystrybuowania wytworów poligrafii podziemnej. Koncesję na obrót dewocjonaliami, w tym okolicznościowymi obrazkami z papieżem, uzyskały jedynie wydzielone punkty „Veritas”, które jednak nie były w stanie zaspokoić wszystkich potrzeb wiernych. Z konieczności więc, przy wykorzystaniu techniki stempelkowej, metodami chałupniczymi produkowano w domach pamiątkowe druczki, które rozprowadzano w trakcie uroczystości5 ${ }^{54}$. Część tych artefaktów posiadała znaki „Solidarności” i sugestywną ikonografię o charakterze politycznym. Na druczkach w postaci pocztowych kartek papież był ukazany jako trybun i mentor Polaków, często w otoczeniu robotników lub kapelanów związku: księży Jerzego Popiełuszki i Henryka Jankowskiego. Niemniej zdaniem Wojciecha Jaruzelskiego, który swoje przemyślenia prezentował w kwietniu 1987 roku na posiedzeniu Sekretariatu KC PZPR, najgroźniejszą formą oddziaływania Kościoła na wiernych były dewocyjne obrazki z modlącym się papieżem ${ }^{55}$. Wobec powszechnego przekonania o świętości Jana Pawła II zapewnienie wyrażone we wspomnianym motywie modlitwy „za nas” utrwalało sąd o rychłej zgubie komunistów. W tym też przypadku praktycznie po 1989 roku nie obserwujemy powielania kartek z zatroskanym papieżem. Dominują sceny błogosławieństwa i emocjonalnej ekspresji ${ }^{56}$. Dewocyjna

53 K. Knoch, Regionalna Komisja Koordynacyjna w Gdańsku w latach 1982-1989, w: Solidarnośc podziemna 1981-1989, red. A. Friszke, Warszawa 2006, s. 220-222; A. Friszke, Regionalny Komitet Wykonawczy Mazowsze. Powstanie, struktura, dziatalność (1981-1986), w: Solidarność podziemna 1981-1989, red. A. Friszke, Warszawa 2006, s. 455-457.

54 Por. M. Kała, Wtadze wobec drugiej pielgrzymki Ojca Świętego do Ojczyzny, ,Biuletyn IPN" 2002, nr 7, s. 60-61, 63.

55 A. Dudek, Gratulacje i obawy, „Biuletyn IPN” 2005, nr 4, s. 30.

56 M. Parzuchowska, Święte obrazki. Bóg i Ojczyzna, dz. cyt., s. 33-34. 
wytwórczość będzie zaś bardziej hagiograficzna niż na zachodzie Europy, gdzie wizerunek papieża mocno się skomercjalizuje.

\section{Podsumowanie}

Formujący się na przestrzeni ostatnich dwóch stuleci przekaz ikonograficzny na obrazku religijnym steruje w stronę profanizacji urzędu papieskiego. Jego funkcja sakralna ustępuje czysto reprezentacyjnej. Humanizacji sprzyja klimat ideowy związany z dyskursem wokół prymatu i nieomylności papieża w sprawach wiary. Dążenie do kolegialnego ujęcia władzy ziemskiego namiestnika Chrystusa odbija się na formie prezentacji papieża jako jednego z nas: jego autorytet przyjmujemy nie $z$ racji transcendentnej nominacji, ale w związku z własnym, indywidualnym wyborem. Ten sposób odbioru sprzyja kreacji marketingowej realizowanej przez wyspecjalizowane agendy kościelne, które powielają obraz dostępnego i przyjaznego ludziom biskupa-urzędnika. Pomimo oporów pojedynczych papieży-charyzmatyków, jak Jan Paweł II czy Benedykt XVI, pragnących formować własną politykę wizerunkową, przekaz utrwala się i osłabia tradycyjnie pojmowane znaczenie urzędu nauczycielskiego Kościoła. Jako otwarte pozostaje jednak pytanie, czy w tym regresie ikonograficznym nie tkwi siła papiestwa, które przecież zgodnie $z$ ewangelicznym przekazem „W słabości się doskonali”. Możliwe, że drogą kolejnych pontyfikatów będzie bardziej otwarte podejście do obrazków z watykańskim imprimatur aż po rezygnację z ich dewocyjnego przeznaczenia.

\section{Bibliografia}

Archiwum Akt Nowych, Główny Urząd Kontroli Prasy, Publikacji i Widowisk, Dziatalność Kościota rzymsko-katolickiego 1958-1963, sygn. 125/303, Notatka informacyjna w sprawie nadsytanych do kraju obrazków religijnych.

Arturo Mari-cztowiek, którego zdjęcia opowiadają historię, „Niedziela” 2007, $\mathrm{nr} 41$.

Banaszak M., Z dziejów dyplomacji watykańskiej. Poselstwa obediencyjne w latach 1534-1605, cz. I, ATK, Warszawa 1975.

Borello L., Arte e devozione nelle immaginette (sec. XVIII-XX), Scuola Grafica Salesiana, Torino 1991. 
Cammarano F., Florian A., Santini e Storia di un Editore parigino. Maison Bouasse-Lebel, Astegiano, Marene 2009.

Cook Ch., Stevenson J., Leksykon nowożytnej historii Europy, przeł. W. Gałąska, Książka i Wiedza, Warszawa 2000.

Dudek A., Gratulacje i obawy, „Biuletyn IPN” 2005, nr 4.

Encyclopedia of nineteenth-century photography, red. J. Hannavy, Routledge, New York 2008.

Encyklopedia katolicka, t. 17, red. E. Gigilewicz, Wydawnictwo KUL, Lublin 2012.

Engels T.M., Das kleine Andachtsbild. Prägedrucke und Stanzspitzenbilder des. 19. Jahrbunderts, Verlag Aurel Bongers, Recklinghausen 1983.

Fischer-Wollpert R., Leksykon papieży, przeł. B. Białecki, Znak, Kraków 1996.

Fitych T., Obraz biskupów polskich w oczach nuncjuszów papieskich z potowy XVII wieku, w: Od Kijowa do Rzymu. Z dziejów stosunków Rzeczpospolitej ze Stolica Apostolskq i Ukrainq, red. M.R. Drozdowski, W. Walczak, K. Wiszowata-Walczak, Uniwersytet w Białymstoku, Białystok 2012.

Friszke A., Regionalny Komitet Wykonawczy Mazowsze. Powstanie, struktura, dziatalność (1981-1986), w: Solidarnośc podziemna 1981-1989, red. A. Friszke, Instytut Studiów Politycznych PAN, Stowarzyszenie „Archiwum Solidarności”, Warszawa 2006.

Grigioni E.G., Pranzini V., Santini. Piccole immagini devozionali a stampa e manufatte dal 17 al 20 secolo, Essegi, Ravenna 1990.

Grześkowiak R., Niedźwiedź J., Nieznane polskie subskrypcje do emblematów Ottona van Veen i Hermana Hugona. Przyczynek do funkcjonowania zachodniej grafiki religijnej w kulturze staropolskiej, „Terminus” 2012, z. 1.

Jarkiewicz K., Ikona polskiej pamięci. Kult Matki Boskiej Częstochorwskiej w świecie, w: Pamięć, kultura, edukacja, red. P. Bieś SJ, M. Chrost, B. Topij-Stempińska, Akademia Igntianum w Krakowie, Wydawnictwo WAM, Kraków 2011.

Kała M., Wtadze wobec drugiej pielgrzymki Ojca Świętego do Ojczyzny, „Biuletyn IPN” 2002, nr 7.

Kelly J.D.N., Encyklopedia papieży, przeł. T. Szafrański, PIW, Warszawa 1997.

Knoch K., Regionalna Komisja Koordynacyjna w Gdańsku w latach 1982-1989, w: Solidarność podziemna 1981-1989, red. A. Friszke, Instytut Studiów Politycznych PAN, Stowarzyszenie „Archiwum Solidarności”, Warszawa 2006.

Łatka R., Polityka wtadz PRL wobec Kościota katolickiego w województwie krakowskim w latach 1975-1980, w: PRL na pochylni (1975-1980), red. M. Bukała, D. Iwaneczko, IPN. Oddział w Rzeszowie, Rzeszów 2017. Majchrzak G., (Nie)chciany pielgrzym, „Biuletyn IPN” 2005, nr 4. 
McBrien R.P., Leksykon papieży. Pontyfikaty od Piotra Apostota do Jana Pawta II, przeł. B. Mierzejewska, A. Miziołek, Świat Książki, Warszawa 2003.

McDannell C., Material Christianity: Religion and Popular Culture in America, Yale University Press, New Haven 1995.

Misztal H., Kult świętych, obrazów i relikwii w Kościele katolickim w aspekcie prawa kanonizacyjnego, „Roczniki Nauk Prawnych”1997, t. 7.

Parzuchowska M., Święte obrazki. Bóg i Ojczyzna, Oficyna Wydawniczo-Poligraficzna „Adam”, Warszawa 2016.

Parzuchowska M., Święte obrazki. Częśc 1. Znak Krzyża Świętego, Oficyna Wydawniczo-Poligraficzna „Adam”, Warszawa 2012.

Parzuchowska M., Święte obrazki. Czzęś́ 2. Życie Świętej Rodziny, Oficyna Wydawniczo-Poligraficzna „Adam”, Warszawa 2013.

Parzuchowska M., Święte obrazki. Częś́ 3. Święci i btogostawieni, Oficyna Wydawniczo-Poligraficzna „Adam”, Warszawa 2015.

Podręczna Encyklopedya Kościelna, opr. S. Gall, t. XXXI-XXXII, Księgarnia Gebethnera i Wolffa, Warszawa 1913.

Przywara A., Przedstawienia dewocyjne na obrazkach świętych jako przedmiot zainteresowań kolekcjonerskich, „Resovia Sacra” 2014, R. 21.

Riebling M., Church of Spies: The Pope's Secret War Against Hitler, Basic Books, New York 2015.

Schatz K., Prymat papieski od początków do wspótczesności, przeł. E. Marszał, J. Zakrzewski, Wydawnictwo WAM, Kraków 2004.

Spamer A., Das kleine Andachtsbild vom XIV. bis zum XX. Jahrbundert, Bruckmann Verlag, München 1930.

Terlecki R., Miecz i tarcza komunizmu. Historia aparatu bezpieczeństwa w Polsce 1944-1990, Wydawnictwo Literackie, Kraków 2007.

The Catholic Encyclopedia, t. 15, red. Ch.G. Herbermann, E.A. Pace, C.B. Pallen, The Encyclopedia Press, New York 1912.

Wojtyska H.D., Papiestwo w XV-XVII w. w poszukiwaniu wtasnej tożsamości, „Kwartalnik Historyczny”1985, nr 4.

Wolleh L., Das Konzil, II Vatikanisches Konzil (The Council, Vatican II Ecumenical Council), Christian Belser Verlag, Stuttgart 1965.

Zdementowano polskie pochodzenie Piusa X. Na historycznym kongresie w Opolu na Ślasku, „L'Osservatore Romano”2013, nr 7.

Żurek J., „Da un paese lontano... Polscy biskupi i kaptani u śr. Piotra (999-1978), „Biuletyn IPN” 2005, nr 4.

\section{ADRES DO KORESPONDENCJI:}

Dr Katarzyna Jarkiewicz

Akademia Ignatianum w Krakowie

e-mail: k.jarkiewicz.ign@gmail.com 